\title{
Determination Residues of Penicillin G and Cloxacillin in Raw Cow Milk Using Fourier Transform Near Infrared Spectroscopy
}

\author{
Michaela Dračková ${ }^{1}$, Pavlína Navrátilová ${ }^{1}$, Luboš Hadra², Lenka Vorlová1, \\ Lenka Hudcová ${ }^{1}$
}

\begin{abstract}
${ }^{1}$ Department of Milk Hygiene and Technology, Faculty of Veterinary Hygiene and Ecology, University of Veterinary and Pharmaceutical Sciences Brno

${ }^{2}$ Tyco Electronics Czech s.r.o. Kurrim, Czech Republic
\end{abstract}

Received June 6, 2008

Accepted June 30, 2009

\begin{abstract}
The objective of this study was to study the use of Fourier transform near infrared spectroscopy (FTNIR) combined with the partial least square (PLS) method for determining the residues of penicillin and cloxacillin in raw milk. The spectra were measured in the reflectance mode with transflectance cell in the spectral range of $10,000-4,000 \mathrm{~cm}^{-1}$ with 100 scans. Calibration models were developed. They were assessed statistically based on correlation coefficients $(\mathrm{R})$ and standard errors of calibration (SEC). For penicillin, the following values were established: $\mathrm{R}=0.951$ and $\mathrm{SEC}=0.004$. For cloxacillin, they were $\mathrm{R}=0.871$ and $\mathrm{SEC}=0.007$. These calibration models were verified later with cross-validation. Better results were obtained in the calibration and validation models that were developed on milk samples coming from one farm. Using FT-NIR, the maximum residue limit (MRL) of cloxacillin in milk can be determined. However, standard errors of calibration and validation for penicillin $\mathrm{G}$ exceed the fixed MRL. FT-NIR spectroscopy is not a suitable method for accurate determination of these substances in raw milk. Variability in milk composition has a major influence on detection of substances present at very low concentrations.
\end{abstract}

Near-infrared spectroscopy, antibiotics, milk

Monitoring residual contents of veterinary drugs and biologically active substances in raw materials and foodstuffs of animal origin is carried out for ethical, hygiene, technological and ecological reasons. The residues of these substances may present pharmacological toxicological, microbiological and immunopathological health risks for humans, that need to be taken into consideration (Heeschen 1993; Honkanen-Buzalski and Reybroeck 1997).

Veterinary drugs and biologically active substances administered to lactating dairy cows can be passed to milk at various levels. The predominant source of milk contamination with antibiotics is the intramammary (intracisternal) application of a specific antibiotic. Other ways of secretory milk contamination are percutaneous, intrauterine, subcutaneous, intramuscular and intravenous application of antibiotics (Heeschen and Blüthgen 1991). Most often used antibacterial substances in lactating cows for bacterial infection treatment are $\beta$-lactam antibiotics (Honkanen-Buzalski and Reybroeck 1997). Penicillins constitute the most important group of antibiotics. The toxicity of penicillins is very low but they can induce an allergic reaction in human skin or elsewhere. On rare occasions, they can even cause the anaphylactic shock. Although reports of allergic reactions coinciding with antibiotic residue intakes from food are rare, sensitive individuals are at risk. Most allergic reactions that have been reported in literature are caused by penicillin to which up to $10 \%$ of population is sensitive (Botsoglou and Fletouris 2001; WHO 1990). Cloxacillin is a representative of the penicillinase-resistant penicillins. It ranks among the most used isoxazolyl-penicillins, mainly in the therapy and prevention of Staphylococcus aureus-induced mastitis (Botsoglou and Fletouris 2001).

Address for correspondence:

MVDr. Michaela Dračková, Ph.D

Department of Milk Hygiene and Technology

University of Veterinary and Pharmaceutical Sciences

Palackého 1/3, 61242 Brno, Czech Republic
Phone: +420 541562714

Fax: +420 541562711

E-mail: drackovam(a)vfu.cz

http://www.vfu.cz/acta-vet/actavet.htm 
Due to the fact that $\beta$-lactam antibiotics are drugs often opted for in veterinary practice, a number of assays have been developed for its determination in milk. Primary agricultural production and dairy industry have been using mainly the microbiological inhibition assays (Delvo-test, COPAN test, BR-test) and rapid assays (Penzym test, Beta-Star test, Delvo-X-Press test, Idexx Snap test and others) in order to determine the $\beta$-lactam antibiotics residue. Methods such as ELISA, high performance liquid chromatography and high voltage electrophoresis enable the identification and quantitative determination of antibiotics (Mũller 1995).

Spectroscopy in the NIR area has been used in food processing industry and agriculture since 1960's. In dairy industry NIR spectroscopy is used mostly for determining the main components in milk and dairy products. However, it can also be used to establish the sensory, physical and chemical properties (Š́ustová et al. 2007; Čurda et al. 2002; Růžičková a Šustová 2006). This technique is non-destructive and provides fast and accurate measurements of components (Lee 2004). Very few spectroscopic applications have been shown to detect analytes at the ppb level. Only one study has been done on the application of FT-NIR and Fourier transform mid-infrared spectroscopy (FT-MIR) for detecting antimicrobial residues in milk (Sivakesava and Irudayaraj 2002).

The objective of this project was to study the possibility of use of FT-NIR spectroscopy for determining the residues of selected antibiotics - penicillin $\mathrm{G}$ and cloxacillin in raw milk.

\section{Materials and Methods}

For calibration sample preparation, the antibiotic preparations of penicillin $\mathrm{G}$ (Penicillin G sodium salt, P 3032, Sigma Aldrich, Inc.) and cloxacillin (Cloxacillin sodium salt monohydrate, Sigma Aldrich Inc., C 9393) were used, as well as bulk tank samples of raw cow milk collected at 3 farms. Stock antibiotic solutions at the active agent concentrations of $0.2 \mathrm{mg} \cdot \mathrm{ml}^{-1}$ were prepared by dissolving the antibiotic preparation in a $0.1 \mathrm{M}$ phosphate buffer. Further dilution of the stock antibiotic solution with deionized water yielded working solutions $\left(0.00002\right.$ to $\left.0.006 \mathrm{mg} \cdot \mathrm{ml}^{-1}\right)$. Calibration samples were prepared by mixing $100 \mu \mathrm{l}$ of a standard antibiotics solution and $9.9 \mathrm{ml}$ of raw cow milk. The minimum concentration of antibiotics in the samples was $0.0002 \mathrm{mg} \cdot \mathrm{l}^{-1}$ $\left(0.00019 \mathrm{mg} \cdot \mathrm{kg}^{-1}\right)$, the maximum one was $2 \mathrm{mg} \cdot \mathrm{l}^{-1}\left(1.9419 \mathrm{mg} \cdot \mathrm{kg}^{-1}\right)$. Two groups of samples with a defined concentration of antibiotics were prepared from bulk milk coming from one farm and from various farms ( 3 farms). At the same time, spectra of the samples obtained from various farms without added antibiotics were measured.

Raw cow milk samples were held at the temperature of $40{ }^{\circ} \mathrm{C}$, cooled to $20{ }^{\circ} \mathrm{C}$ and mixed with standard antibiotic solutions and transferred onto Petri dishes. Samples were measured using the Nicolet Antaris Near-IR Analyzer (Thermo Electron Corporation, Madison, USA) in the spectral range of 10,000-4,000 $\mathrm{cm}^{-1}$. The means of 100 scans were taken for each sample. Data were recorded as $\log 1 / R$, where $R$ is the reflectance energy. The spectra were measured on the integration sphere in the reflectance mode with the use of a transflectance cell $0.1 \mathrm{~mm}$ wide. Each sample was analysed three times and the average spectrum was used for calibration. Spectral data of the selected spectral regions were processed with the TQ Analyst version 6.2.1.509 (Thermo Electron Corporation, Madison, USA) software using the PLS (partial least square) method (Haaland and Thomas 1988ab) and verified by cross-validation (with the same samples). Cross-validation was used in all cases to minimize the risk of over-fitting the calibrations of penicillin $\mathrm{G}$ and cloxacillin when evaluating calibration accuracy. One of the standards is always removed during this procedure and a new model is created from the remaining calibration data, which is used for the calculation of the concentration vector of the removed standard. Calculated deviations from the declared content of components of the removed standard were then statistically evaluated (Mlček et al. 2006). Outlying standards that had inaccurately established reference values or where there was a spectral error in the measured spectrum were removed using diagnostic tools (Spectrum Outlier and Leverage) (Šustová et al. 2007). The results were processed with statistical and graphic software STAT Plus (Matoušková et al. 1992). Paired $t$-test was used for comparison of the values measured with FT-NIR with the laboratory values obtained with dilution.

\section{Results and Discussion}

Calibration models were developed using milk from various farms $(91$ samples with added penicillin and 84 milk samples with added cloxacillin). In addition, calibration models developed for samples from only one farm were used (30 samples with penicillin and with cloxacillin). The ranges of reference values for the given antibiotics 
Table 1. Reference values $\left(\mathrm{mg} \cdot \mathrm{kg}^{-1}\right)$

\begin{tabular}{|l|c|c|c|c|c|}
\hline Indicator & $\mathrm{n}$ & $\mathrm{x}$ & $\mathrm{x}_{\min }$ & $\mathrm{x}_{\max }$ & $\mathrm{SD}$ \\
\hline Penicillin* & 91 & 0.01621 & 0.00000 & 0.09709 & 0.01959 \\
\hline Penicillin** & 30 & 0.01619 & 0.00019 & 0.05814 & 0.01640 \\
\hline Cloxacillin* & 84 & 0.01539 & 0.00000 & 0.09741 & 0.01890 \\
\hline Cloxacillin** & 30 & 0.01642 & 0.00019 & 0.05816 & 0.01624 \\
\hline
\end{tabular}

$\mathrm{n}$ - samples number, $\mathrm{x}$ - average, $\mathrm{x}_{\min }-$ minimum value, $\mathrm{x}_{\max }$ maximum value, $\mathrm{SD}$ - standard deviation,

* - milk samples from various farms, ** - sample from only one farm

had the form of standard error of the mean (Table 1). Another important diagnostic tool is the dependence of the PRESS (predicted residual error sum of squares) on the number of PLS factors used for calibration that enable prediction of optimum number of factors (Čurda et al. 2002). The PRESS value is an indicator of the calibration error due to the PLS method. An optimum course of PRESS is indicated by a steep decline and further decrease is slow. It is apparent that the optimum number of PLS factors will be found when the PRESS value is at its minimum. A high number of PLS factors reduce the ability to predict because PRESS involves spectral noise, too (Jankovská and Šustová 2002). The best calibration model was selected on the basis of the correlation coefficient (R) and standard errors of calibration (SEC). Reliability of the calibration model was verified using the cross-validation method (Sivakesava and Iruday araj 2002). To develop validation models, the same set of samples as when calibrating was used. There is a strong dependence between the reference values and the predicted ones (Figs 1 and 2). Validation accuracy was assessed on the basis of the correlation coefficient and the standard error of validation (SECV) (Sivakesava and Irudayaraj 2002). The calibration and validation results for the penicillin and cloxacillin contents are presented in Table 2. To develop calibration models for predicting the concentrations of penicillin and cloxacillin in milk, the derived FT-NIR of the spectrum was used. Better validation results for penicillin, and calibration and validation results for cloxacillin were found in models that were developed for milk samples originating from the same farm (Table 2). Paired $t$-test revealed no significant differences $(p=0.05)$ between the reference values and those calculated with NIR for penicillin and cloxacillin.

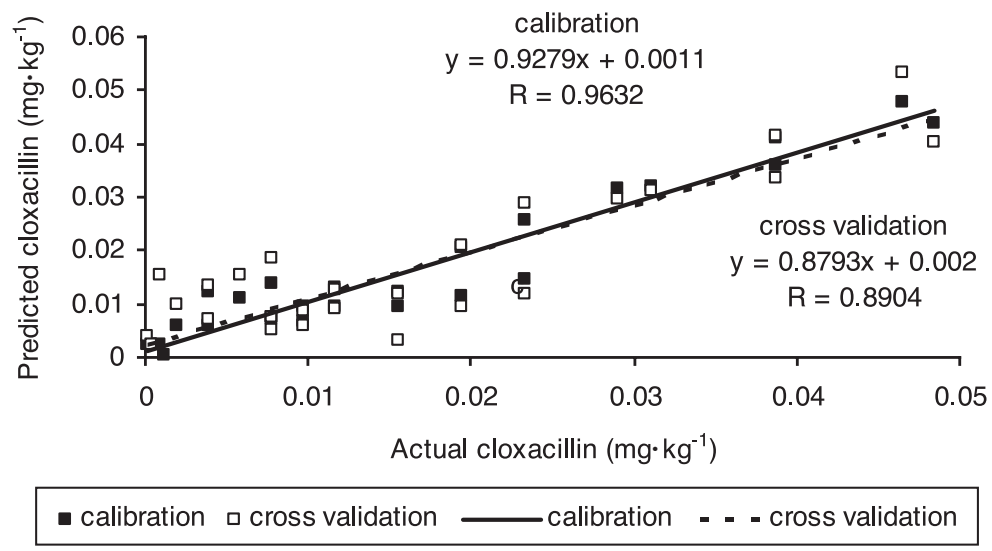

Fig. 1. Calibration and validation models for cloxacillin (sample from only one farm) 


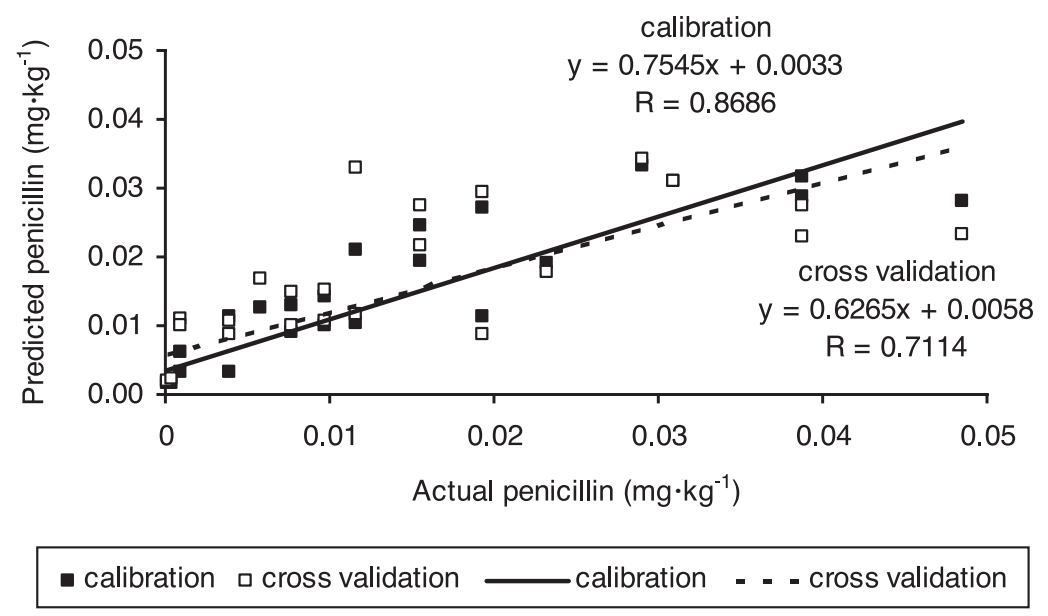

Fig. 2. Calibration and validation models for penicillin (sample from only one farm)

Table 2. Calibration and validation results for $\beta$-lactam antibiotics in milk

\begin{tabular}{|l|c|c|c|c|c|c|c|}
\hline \multirow{2}{*}{ Indicator } & $\mathrm{n}$ & \multirow{2}{*}{$\begin{array}{c}\text { PLS } \\
\text { factors }\end{array}$} & \multirow{2}{*}{ derivative } & \multicolumn{2}{|c|}{ calibration } & \multicolumn{2}{c|}{ validation } \\
\cline { 5 - 8 } & & & $\mathrm{R}$ & $\mathrm{SEC}$ & $\mathrm{R}$ & SECV \\
\hline Penicillin * & 83 & 5 & 2 & 0.951 & 0.004 & 0.623 & 0.011 \\
\hline Penicillin ** & 27 & 5 & 1 & 0.869 & 0.007 & 0.711 & 0.010 \\
\hline Cloxacillin * & 70 & 3 & 2 & 0.871 & 0.007 & 0.661 & 0.010 \\
\hline Cloxacillin** & 29 & 7 & 0 & 0.963 & 0.004 & 0.890 & 0.007 \\
\hline
\end{tabular}

$\mathrm{R}$ - correlation coefficient, SEC - standard error of calibration, SECV - standard error of validation, $\mathrm{n}$ - samples number after removed outlying, * - milk samples from various farms, **-sample from only one farm

Better validation results for penicillin $\mathrm{G}$, and calibration and validation results for cloxacillin in models that were developed for milk samples from the same farm may be due to the following factors. Milk is a very complex mixture containing a large number of lipids, proteins, vitamins, and minerals as well as somatic cells and bacteria. These milk components exercise a major influence on determination of antibiotics in milk (Sivakesava and Irudayaraj 2002). Spectroscopy in the NIR region makes use of absorption bands that involve overtones and combinations of valence and deformation vibrations (Čurda et al. 2002). In the NIR spectra bands of light atoms dominate. Their bonds vibrate with a high frequency (especially $\mathrm{C}-\mathrm{H}, \mathrm{N}-\mathrm{H}$ and $\mathrm{O}-\mathrm{H}$ ). The spectra in this region are vibrational ones that provide information about the structure and bonding in the molecule, as do the spectra in the mid-infrared region (MIR) (Bokobza 2002). The distinguishing feature is the fact that NIR spectra are much more complicated and their interpretation is not as straightforward and simple as in the sharply and clearly divided bands that usually correspond to the fundamental vibrations in the MIR spectra, where analytical bands can be easily found. They are then usually used in univariance calibration to determine the quantity or in search programmes for determination of the product quality (Jankovská 2004). In milk samples, interpretation of the complex NIR spectra is difficult because the incidence of various structures in the chemical compounds is a result of bands overlapping and the specific bands in the spectra can contain information from more than one type of molecular vibrations. NIR absorbance for various generic functional groups can correlate with the main milk components 
(Sivakesava and Irudayaraj 2002). Information found in the NIR spectra can nowadays be collected using chemometric techniques that employ the whole spectral information (Čurda at al. 2002). The disadvantage of FT-NIR spectroscopy is that it is not a suitable method for determination of minority components (Jankovská 2004).

There are few studies that use FT-NIR spectroscopy for the detection of residues of veterinary medicinal products in milk. Sivakesava and Irudayaraj (2002) employed FTNIR and FT-MIR methods for rapid detection of tetracycline antibiotics. Their calibration models displayed square correlation coefficients in the range of $0.63-0.90$, depending on the region and derivation used. They found that prediction errors for FT-NIR are too high. The given MRL (maximum residue limit) in raw milk are $0.004 \mathrm{mg} \cdot \mathrm{kg}^{-1}$ and $0.03 \mathrm{mg} \cdot \mathrm{kg}^{-1}$ for penicillin and cloxacillin, respectively (Council Regulation (EEC) No 2377/90). Using FT-NIR, the MLR values of cloxacillin in milk can be determined. The standard errors of calibration and validation exceed the specified MRL values for penicillin. The disadvantage of FT-NIR spectroscopy, as mentioned above, is that the method is not suitable for determination of minority components - confirmed in the case of determination of very low concentration of penicillin. FT-NIR spectroscopy could be used for detection of residues of penicillin $\mathrm{G}$ and cloxacillin only in milk samples with constant composition. Variability in milk composition has a major influence on detection of substances present at very low concentrations; our results have confirmed it. Better results have been reached in the calibration and validation models that were developed for milk samples coming from one farm. FT-NIR spectroscopy is suitable only for semi-quantitative determination of residues of penicillin $\mathrm{G}$ and cloxacillin.

\section{Stanovení penicilinu G a kloxacilinu v syrovém kravském mléce pomocí spektrometrie v blízké infračervené oblasti s Fourierovou transformací}

Cílem práce bylo ověření možnosti využití blízké infračervené spektroskopie s Fourierovou transformací (FT-NIR), v kombinaci s metodou částečných nejmenších čtverců (PLS), pro stanovení reziduí penicilinu G a kloxacilinu v syrovém kravském mléce. Spektra byla naměřena $\mathrm{v}$ modu reflektance $\mathrm{s}$ transflektanční kyvetou ve spektrálním rozsahu 10000 $4000 \mathrm{~cm}^{-1}$ se 100 scany. Pro sledované parametry byly vytvořeny kalibrační modely, které byly statisticky zhodnoceny na základě korelačních koeficientů $(R)$ a směrodatných odchylek kalibrace (SEC). Pro penicilin G byly zjištěny hodnoty $\mathrm{R}=0,951$ a $\mathrm{SEC}=0,004$ a pro kloxacilin $\mathrm{R}=0,871$ a $\mathrm{SEC}=0,007$. Vytvořené kalibrační modely byly následně ověřeny pomocí cross-validace. Lepší výsledky byly dosaženy u kalibračních a validačních modelů u vzorků pocházejících z jedné farmy. Pomocí FT-NIR je možné detekovat stanovený maximální reziduální limit (MRL) kloxacilinu v mléce. Směrodatné odchylky kalibrace a validace pro penicilin G překračují stanovený MRL. FT NIR není vhodná pro presné stanovení těchto látek v mléce. Variabilita ve složení mléka má výrazný vliv na stanovení látek př́itomných v mléce ve velmi nízkých koncentracích.

\section{Acknowledgements}

This study was supported by the Grant 6215712402 "Veterinary aspects of food safety and quality" of the Ministry of Education, Youth and Sports of the Czech Republic.

\section{References}

Bokobza L 2002: Origin of near-infrared absorption bands. In: Siesler HW, Ozaki Y, Kawata S, Heise HM (Ed.): Near-infrared spectroscopy. Principles, instruments, applications. Wiley-VCH Verlag, Weinheim, pp. 11-41 Botsoglou NA, Fletouris DJ 2001: Drug residues in foods. Marcel Dekker, New York, 1194 p.

Council Regulation (EEC) No 2377/90 of 26 June 1990: Laying down a Community procedure for the establishment of maximum residue limits of veterinary medicinal products in foodstuffs of animal origin. Official Journal of the European Communities, L 224: 1-8 
Čurda L, Kukačková O, Novotná M 2002: Near-infrared spectroscopy and its application to milk and dairy products analysis. Chem Listy 96: 305-310

Haaland DM, Thomas EV 1988a: Partial lest-squares methods for spectral analyses. 1. Relation to other quantitative calibration methods and the extraction of qualitative information. Anal Chem 60: 1193-1202

Haaland DM, Thomas EV 1988b: Partial lest-squares methods for spectral analyses. 2. Application to simulated and glass spectral data. Anal Chem 60: 1202-1208

Heeschen WH 1993: Residues of antibiotics and sulfonamides in milk. Bulletin of the IDF No. 283. IDF, Brussels, pp. 3-13

Heeschen WH, Blüthgen A 1991: Veterinary drugs and pharmacologically active compounds. Monograph on residues and contaminants in milk and milk products. IDF, Brussels, pp. 13-69

Honkanen-Buzalski T, Reybroeck W 1997: Antimicrobials. Monograph on residues and contaminants in milk and milk products. IDF, Brussels, pp. 26-33

Jankovská R 2004: Využití blízké infračervené spektroskopie (NIR) při hodnocení vybraných mléčných produktů (Application of near-infrared spectroscopy (NIR) for determination of chosen dairy products). $\mathrm{PhD}$. Thesis, Mendel Univ Agric Forestry Brno, Brno, 178 p.

Jankovská R, Šustová K 2002: Využití NIR spektroskopie k hodnocení složení jogurtů (Use of NIR spectroscopy for evaluation of yoghurt composition). Mlékařské listy 71: 18-20

Lee KA 2004: Review of applications of near infrared spectroscopy to food analysis. The NIR Spectrum 2: 11-16

Matoušková O, Chalupa J, Cígler M, Hruška K 1992: STAT-Plus uživatelská příručka, verse 1.01. (STAT Plus Manual, version 1.01.). Veterinary Research Institute, Brno. $168 \mathrm{p}$.

Mlček J, Šustová K, Simeonovová J 2006: Application of FT NIR spectroscopy in the determination of basic chemical composition of pork and beef. Czech J Anim Sci 51: 361-368

Mũller DJS 1995: Present state and trends in the use of veterinary antimicrobials with particular reference to dairy cows. In: Proceedings of Symposium on residues of antimicrobial drugs and other inhibitors in milk. IDF, Brussels, pp. 15-21

Rủžičková J, Šustová K 2006: Determination of selected parameters of quality of the dairy products by NIR spectroscopy. Czech J Food Sci 24: 255-260

Sivakesava S, Irudayaraj J 2002: Rapid determination of tetracycline in milk by FT-MIR and FT-NIR spectroscopy. J Dairy Sci 85: 487-493

Šustová K, Růžičková J, Kuchtík J 2007: Application of FT near spectroscopy for determination of true protein and casein in milk. Czech J Anim Sci 52: 284-291

WHO 1990: Evaluation of certain veterinary drug residues in food. Thirty-sixth Report of the Joint FAO/WHO Expert Committee on Food Additives. WHO Technical Report Series No. 799. WHO, Geneva, 68 p. 